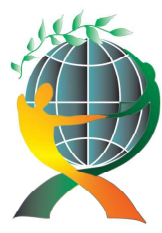

\author{
(online) $=$ ISSN $2285-3642$ \\ ISSN-L = $2285-3642$ \\ Journal of Economic Development, Environment and People \\ Volume 6, Issue 4, 2017
}

URL: http://jedep.spiruharet.ro

e-mail: office jedep@spiruharet.ro

\title{
Discourses of leadership change or changes of leadership discourse?
}

\author{
Cornelia ILIE ${ }^{1}$ \\ ${ }^{1}$ Malmö University, Sweden \\ 2 cornelia.ilie@gmail.com
}

\begin{abstract}
The present study focuses on the discursively performed leadership during periods of transition and change in the context of competition-driven organizations. It explores discourses of leadership in a diachronic perspective, scrutinising the ways in which they construct and re-construct corporate and culturerelated identities. Drawing on interviews and press conferences with several CEOs of two multinational companies, Nokia (Finland) and Ericsson (Sweden), an investigation of the challenges of leadership branding was carried out in a discourse-analytical and pragma-rhetorical perspective. Particular emphasis has been placed on systematically comparing the presentations in letters to employees by the CEOs of Nokia and Ericsson. This comparative study provides evidence for the internal and external challenges underlying leadership discursive construction and re-construction aimed at ensuring a consistent interconnectedness between a company's values and its competitive qualities.
\end{abstract}

Keywords: eadership, discourse, change, Nokia, Ericsson, values, identities

JEL Codes: M1, M21

\section{Introduction}

In many business organizations, people are becoming increasingly aware that there is an interdependence between organizational outcomes and the impact of leadership discourses (Putnam and Fairhurst 2001; Clifton 2012). This is particularly noticeable in times of change, which is one of the few certainties an entrepreneur can count on in business. Change comes in different forms and even a minor change can have big consequences, where there is a fine line between success and failure.

A significant paradox can be noticed in current research on leadership. While theories of leadership convincingly show that leadership is a distributed and participative process rather than the individual action undertaken by any one person, considerable attention is equally being paid to influential leadership discourses widely circulated in the traditional media, social media and the public sphere, which continue to focus on the profile, role, (mis)behaviour, (in)actions and (un)successful communication skills of the CEO, who is ultimately held responsible and accountable for 'doing' leadership that amounts to change, success or failure of the company. It is particularly symptomatic that nowadays the multilayered leadership performance of a CEO - both discourse-shaped and discourse shaping - is under continuous scrutiny, 


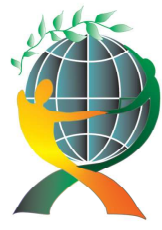

\author{
(online) $=$ ISSN $2285-3642$ \\ ISSN-L = 2285 - 3642 \\ Journal of Economic Development, Environment and People \\ Volume 6, Issue 4, 2017 \\ URL: http://jedep.spiruharet.ro \\ e-mail: office jedep@spiruharet.ro
}

internally (by board members, collaborators, subordinates) and externally (by shareholders, competitors, customers, business analysts, media reporters).

The words, phrases, feedback and statements expressed by CEOs are quickly noticed and perceived as the externally directed voice, vision and view of the company. This is why it is relevant to note the emergence and development of the 'leadership-as-practice' (L-A-P) movement (Carroll et al. 2008; Raelin 2016a), according to which leadership is conceived of as a practice rather than as residing in the traits or behaviours of particular individuals. The L-A-P approach resonates with closely related leadership traditions, such as collective, shared, distributed and relational leadership. For Raelin, leadership becomes evident when agency appears as a constraint to structure: "Using such resources as self-consciousness and deliberation, agents can use individual and collective reflexivity to overturn the historical contexts and expectations imposed on people and institutions" (p. 5). Although agency is normally exhibited during everyday routines, it becomes more visible during moments of crisis, indeterminacy or uncertainty. An individual's idea or thought may spur other members of the organization to start a creative initiative, to find a way out in a critical situation or to overcome unexpected challenges or disruptions.

\title{
2. Aim and focus of the study
}

The present study examines the interrelatedness between organisational change and leadershipenacted discourses, by focusing on two telecommunication companies, Nokia and Ericsson. In both cases, there is a continuous and deliberate search for a way to revolutionise the concept of IT through the development of competitive, highly performing leadership and organisational teams, motivated through strongly articulated commitment discourses. Drawing on presentations and mission statements of CEOs of two Nordic multi-national companies, Nokia (Finland) and Ericsson (Sweden), a comparative analysis of the challenges of enacting participative leadership is carried out from a discourse-analytical and pragmarhetorical perspective.

The focus of the present study is on the discursively constructed and publicly displayed performance of CEO leadership in the context of competition-driven organizational change. It explores the focus, scope and essence of discourses of leadership in a comparative perspective, scrutinising the ways in which they contribute to constructing and reconstructing organisational and culture-related identities. From an analytical perspective, CEO leadership practices of Nokia and Ericsson are examined as a communicational, relational and context-sensitive phenomenon that is enacted and re-enacted through discursive practice.

Both companies are known to have started with a strong link to their respective national identity, but overtime they have often displayed shifting discursive leadership strategies in the national and international context. Nokia is part of the modernisation process of Finnish society and related to a strong national narrative of catching up, while Ericsson represents the continuation of a proud industrial tradition where Swedes for decades have been a most advanced nation (Lindén 2012). Doing leadership, this has been a cornerstone in the process of discursively and interactively articulating the intermittent recontextualisation and re-invention of these two companies, has at times worked differently in the two cases, in terms of innovative change and competitive advantage. This comparative study exposes stereotypes and counter-stereotypes, providing evidence for the internal and external challenges, as well as the personal and interpersonal dynamics that underlie leadership discursive construction and 


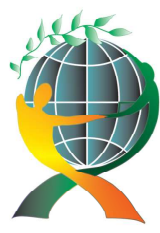

\author{
(online) $=$ ISSN $2285-3642$ \\ ISSN-L = $2285-3642$ \\ Journal of Economic Development, Environment and People \\ Volume 6, Issue 4, 2017 \\ URL: http://jedep.spiruharet.ro \\ e-mail: office jedep@spiruharet.ro
}

reconstruction aimed at ensuring a consistently adaptive interconnectedness between a company's values and its competitive qualities.

\title{
3. Discourse-Driven Change in Business Organisations
}

The process of social change raises questions about causal relations, interdependencies, transitional processes, innovative problem-solving, strategic decision-making, all of which construct and get articulated through discourses (Berger and Luckmann1966). Examining discourses emerging in connection with organisational change enables us to connect particular conceptualisations and representations of leadership in terms of prerequisites, end-goals and relations of power.

Adopting a systemic leadership approach, Beerel (2009) starts from the assumption that organisations are expected to grapple with change at all levels all the time. They break or recreate new paradigms that do not follow a classic cycle path. As a result, she views leadership as fundamentally concerned with the process of change. John P. Kotter, renowned for his work on leading organisational change, found that unsuccessful transitions almost always fail during at least one of the following phases: generating a sense of urgency, establishing a powerful guiding coalition, developing a vision, communicating the vision clearly and often, removing obstacles, planning for and creating short-term wins, avoiding premature declarations of victory, and embedding changes in the corporate culture (Kotter 1988, 1996). Processes of social and institutional change construct and get articulated through discourses of change and changes of discourse. As has been pointed out by Fairhurst and Putnam (2004), organisations may be seen in a perpetual condition of becoming through the ways in which the properties of discourse shape organising. Important transformations often occur when an organisation has a new CEO who is supposed to be an effective leader and to be able to engage in dialogue and communicate appropriately the unavoidability and/or the need for a major change.

\section{Theoretical Approaches to Discourses of Leadership}

A notion of agency relevant to this study was developed by Emirbayer and Mische (1998), who see it as a temporally embedded process of social engagement, and at the same time as a variable and always changing phenomenon. The temporality of agency is manifest in the way social actors display different temporal orientations towards past, present, future since in concrete instances of action all three elements are present, although usually one of them predominates. A discursive perspective on agency conceptualisation (Emirbayer and Mische 1998; Fairhurst and Connaughton2014) and on L-A-P (Raelin $2016 a, b)$ underpins the overarching research question of the present analysis: In what ways and to what extent do discourses of leadership and agency overlap interact and co-construct shared meanings?

Since discourses are socially and contextually co-constructed (Phillips and Hardy 2002), they arise through the interplay of discourse, text, and context. In this respect, socio-pragmatics (Leech 1983; Thomas 1983) offers relevant analytical tools for a context-sensitive approach to patterns and norms of language use, for example, as they are instantiated in the realisation of speech acts (Austin 1962;Searle 1969, 1975).

In order to scrutinise and compare the ways in which discourses of leadership are articulated in the Swedish and the Finnish company, respectively, it is necessary to examine how organisational, cultural and (inter)personal context-specific factors determine particular linguistic choices, and primarily the nature and 


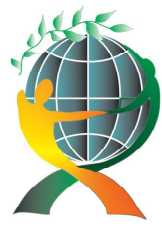

\author{
(online) $=$ ISSN $2285-3642$ \\ ISSN-L = $2285-3642$ \\ Journal of Economic Development, Environment and People \\ Volume 6, Issue 4, 2017 \\ URL: http://jedep.spiruharet.ro \\ e-mail: office jedep@spiruharet.ro
}

force of the speech acts and the corresponding agency-related pronominal forms. Significant aspects of speech act performance are degree of (in)directness, audience involvement and speaker-audience relationship. In particular, the speech acts performed in discourses of leadership can be seen to sometimes reinforce and at other times challenge stereotypical representations of organisationally, interpersonally and culturally situated discursive leadership practices.

Although theorists set forth several categories of speech acts (e.g. assertive, declaratives, expressive, directives, commissives), many studies on organisational discourse have focused particularly on directives or speech acts meant to bring about a particular state of affairs (Hill and Jones 1992; Heracleous and Marshak 2004). As the present analysis will show, the speech acts used in CEO leadership discourses tend to display a much greater diversity and multi-functionality.

\title{
5. Leadership Practices at Ericsson and Nokia
}

During their long history, the two Nordic sister companies, Ericsson and Nokia, came to be seen as "the industrial projections of national identity" (Hayward 1995,p. 2). Over time, Ericsson and Nokia have been close partners in the advancement of mobile phone technology based on the Nordic standard of NMTand later the pan-European GSM that led the fields of different competing standards. The success stories of the two companies often followed converging, but sometimes also diverging, directions.

\section{Nokia-Discourse of Leadership and Change}

By 1998, Nokia's focus on telecommunications and its early investment in GSM technologies had made the company the world's largest mobile phone manufacturer, a position it would hold for 14 consecutive years. After periods of Finnish and Canadian leadership, in 2014the India-born Rajeev Suri (who first joined Nokia in1995, working across the board from production to handling key divisions), was appointed as CEO of Nokia. Under his leadership, Nokia is developing into software and services company that will compete with the likes of Ericsson, Huawei and Google. The most recent acquisitions, the French Alcatel-Lucent, positions Nokia as an innovation leader in next-generation technology and services.

\section{Ericsson - Discourse of leadership and change}

The so-called 'Swedishness' of Ericsson was often stereotypically emphasized by board and leadership team members, especially when recruiting a new CEO. A case in point was the recruitment process in 2002 when the board was looking for a new CEO. The chairman Michael Treschow was searching for a Swede since, in his opinion, Ericsson is a Swedish company with a Swedish management and a Swedish culture (Karlsson \& Lugn 2009). The new CEO recruited in 2003 was indeed a Swede, Carl-Henric Svanberg, who successfully introduced a more informal behaviour and more relaxed leadership communicative style. Hans Vestberg, an international Swede who had management positions for Ericsson in China, Brazil, Mexico and the US, was appointed CEO in January 2010. He actively promoted diversity and inclusion as the basis for innovation and success. In July 2016, Hans Vestberg had to resign, after facing pressure to step down as the company was struggling with profitability in a period of slowing demand and intense competition. Vestberg's leadership discourse style is the focus of the present investigation. 


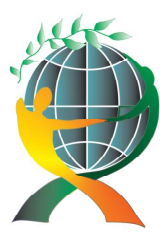

\author{
(online) $=$ ISSN $2285-3642$ \\ ISSN-L = $2285-3642$ \\ Journal of Economic Development, Environment and People \\ Volume 6, Issue 4, 2017 \\ URL: $\underline{\text { http://jedep.spiruharet.ro }}$ \\ e-mail: office jedep@spiruharet.ro
}

\title{
Value-based leadership - Ericsson and Nokia
}

Ericsson and Nokia organisational cultures are each guided by a set of core values in their ways of doing business, making decisions, and overall ways of acting, behaving and communicating internally and externally.

On its website, Ericsson indicates three core values: Respect. Professionalism. Perseverance. They are described as the core values that define Ericsson culture and guide those working for the company in their daily work and in the way they do business.(https://www.ericsson.com/about-us/our-vision)

The Nokia core values are similarly described on the company's website as "designed to guide our decisions, our way of working and the responsibility we have towards our customers and other stakeholders." (http://company.nokia.com/en/about-us/our-company/our-values). Four values are listed and accounted for as embraced by all employees and executives at Nokia:

Respect - We treat each other with respect and we work hard to earn it from others.

Achievement - We work together to deliver superior results and win in the marketplace.

Renewal - We invest to develop our skills and grow our business.

Challenge - We are never complacent and perpetually question the status quo.

A parallel can be drawn between the sets of core values that guide the two companies. The first of the two sets of core values - Respect - is identical for the two companies and is based on a fundamental ethical principle shared by both companies. What actually make the difference between the two companies are Nokia's last two core values: Renewal \& Challenge, which point to basically encouraging and fostering an innovative and challenging spirit in the Nokians.

For obvious reasons, all these core values are widely used as recurring keywords in both internal and external company documents, CEO letters and statements, press releases, a.s.o., and thereby they play an important role in both reflecting and shaping discursively each of the two corporate cultures, as well as their respective leadership styles and practices. At the same time, it is worth noting that they also contribute to spreading common stereotypes about Swedish and Finnish culture-specific business strategies and corporate leadership styles, which may sometimes lead to unfounded overgeneralisations.

\section{Stereotypes and Counter-Stereotypes of Nordic Leadership - the Finnish and Swedish case studies}

The obvious historical similarities between Finland and Sweden have often led to overgeneralisations about an undifferentiated 'Scandinavian culture', with the implicit understanding that all Nordic countries have very similar cultural values (Smith et al, 2003).Some of the most widespread stereotypes about Finnish and Swedish cultures as ascribed to business companies such as Nokia and Ericsson.

- Nokia and Ericsson are often stereotypically seen (both in their home countries and abroad) as representing the national identities of Finns and Swedes respectively, although we know that identities are hardly homogeneous and particularly complex and dynamic phenomena, neither unitary nor static.

- A widely acknowledged view is that in Finland and Sweden business organizations tend to be quite 'flat', with power relatively equally distributed. While the two cultures share elements of a so-called 'Scandinavian type of leadership' (Tyrstrup, 2005), this view can sometimes turn into a stereotype when it 


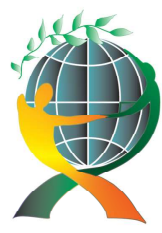

\author{
(online) $=$ ISSN $2285-3642$ \\ ISSN-L = $2285-3642$ \\ Journal of Economic Development, Environment and People \\ Volume 6, Issue 4, 2017 \\ URL: http://jedep.spiruharet.ro \\ e-mail: office jedep@spiruharet.ro
}

is applied indiscriminately to two distinct cultures, which happen to exhibit slightly different models of a basic 'flat' power distribution through leadership among peers (Lämsä, 2010).

- A principle that is stereotypically assumed to be shared by both Finnish and Swedish cultures is the principle of consensus in decision-making, which would reflect their egalitarian and equality values. While it is correct to say that the two cultures are consensus-oriented, this orientation can take different forms in individual instances. Thus, Finnish culture tends to exhibit a "combination of strong consensus and deep controversy" (Luhtakallio 2010: 211), and in Swedish culture consensus is seen primarily as a condition for dialogue, but also as a preferred outcome of the dialogue (Czarniawska-Joerges, 1993; llie, 2007 ).

Leadership discourse stereotypes - the case of CEO letters

In order to analyse and compare the whys and hows of leadership discourse as discourse-in-action in two Nordic companies, the present investigation focuses on the respective CEOs' letters to employees. As leadership agents, CEOs impact the situational context of their company as much as they are impacted by it. The aim of a CEO letter is to build credibility, to impart confidence, to highlight visions, and to convince the audience (i.e. investors, shareholders, stakeholders...) that the company is pursuing effective strategies, and delivering profitable performance. This letter functions as a personal and public statement with multiple potentialities: through it, the CEO of a major corporation exercises his/her power to define social reality for corporate stakeholders, thus shaping the context in which events or proposals are perceived and understood by the public. On Argenti and Forman's view (2004), a CEO is considered the most credible voice of an organization since he/she is well situated to communicate the company's position and core values, and also articulate its major issues of interest.

There are several commonalities between Hans Vestberg, Ericsson's latest CEO and Rajeev Suri, Nokia's current CEO. Both of them belong to the same generation of leaders - Vestberg was born in 1965, Suri in 1967 - ;,both of them had worked for about two decades for their companies prior to being appointed CEOs - Vestberg joined Ericsson in 1991, Suri joined Nokia in 1995 - ; both of them have international working experience. It is therefore interesting to examine, against the backdrop of these commonalities, the elements that distinguish them in terms of their leadership discourse styles as they are manifest in their first CEO letters to employees.

\title{
Challenging leadership discourse stereotypes - Nokia CEO's letter to employees
}

The CEO's motivational goals are meant to reflect and reinforce the organizational core values, to highlight shared experiences, to indicate opportunities and point to challenges to be overcome, while promoting a common organisational identity and commitment. Rajeev Suri is the current CEO of Nokia and the second non-Finnish CEO (after Stephen Elop). His first letter to Nokia's employees, made public in connection with his appointment as CEO (on 3 April 2014), serves both informational and motivational goals. In this letter he reinforces the legitimacy of his newly assumed leadership position by highlighting the emotions (rhetorical pathos) he is experiencing on this occasion. Expressing a feeling of humility is here more than an instantiation of audience-oriented rhetorical pathos, it is an expected attitude to be taken in the context of flat business organizational structures that characterise Finnish (and other Nordic) companies. The next key notion, respect, coincides with the very first of Nokia's core values, and Suri uses it skilfully, alongside with related values, to define Nokia and also to self-define as someone who has already (over 20 years at Nokia) identified himself with the company: "These words and others have defined the 


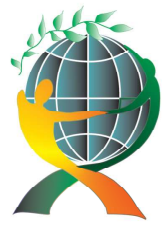

\author{
(online) $=$ ISSN $2285-3642$ \\ ISSN-L = $2285-3642$ \\ Journal of Economic Development, Environment and People \\ Volume 6, Issue 4, 2017 \\ URL: http://jedep.spiruharet.ro \\ e-mail: office jedep@spiruharet.ro
}

company and, in turn, have partly defined me [...] I am part of Nokia and Nokia is part of me." His brief personal narrative is meant to prove that he, born in India and a world traveller, has developed, during his 20 years at Nokia, a Finnish leadership style.

Since Nokia is a multinational corporation, Suri's letter is implicitly aimed at a multicultural workforce. A major challenge for such a letter in a Finland-based multinational company consists in articulating an energizing and goal-unifying discourse that succeeds in targeting and involving a diverse audience of company employees in terms of cultural, educational and professional background. In the underlined passages in (2) above, Suri is open and straightforward in self-defining ("I consider myself an international citizen") and expressing his beliefs ("I tend to focus more on people than on place"), so as to engage and gain the trust of his employees, many of whom constitute an international workforce in this Finland-based multinational company. By pointing to his own culturally and professionally diverse background, he is identifying with the reality of many employees, establishing a closer proximity through the bond of commonalities and shared experience. At the same time, Suri mitigates his claim to international citizenship by providing a complementary claim of belonging to Finland in his capacity of CEO. He does this by means of two symbolic speech acts: an assertive speech act ("As CEO of Nokia, my place is clearly in Finland, where I have lived since 2009"). He is thereby challenging the stereotypical separation of the two claims (eitheror), highlighting instead their complementarities (both-and). Here the counter-stereotypical element in Suri's rhetoric is the claim to Finnish belonging as much as to multiculturalism.

Indicating that Nokia is confronted with a new reality and needs to overcome serious challenges ("removing unnecessary distractions"), he wants to be perceived as a responsible agent of change who is determined to avoid unnecessary risk-taking or short-sighted pursuit of "small cost gain". Rather than showing hesitation in front of unprecedented challenges, or, on the contrary, mindlessly carrying out changes, he assumes instead the pioneering role of a visionary, but careful, leader in times of change. Suri's determination and courage are in line with the Finnish leadership stereotype, but he also displays a counter-stereotypical trait when he recommends exercising prudence when making changes: "We must have the courage to know what to leave behind; to know what we must change and renew.". He upholds his constant eagerness to learn and to ask questions ("I will be asking a lot of questions"), both of which resonate with and correspond to two of Nokia's core values: Renewal and Challenge. Suri emerges here as an enabler of participative leadership, encouraging a consultation dialogue as a two-way street, i.e. both sharing experience with co-workers and motivating them to share information and ideas.

Rajiv Suri's discursive leadership style exhibits both stereotypical and counter-stereotypical patterns of CEO leadership discourse. While generally following a Finnish leadership model that is consensus-based, but also partly authoritative, he also displays the features of a participative leadership discourse whose aim is to motivate and empower the workforce to actively and jointly participate in vision creation, goal setting and problem solving.

\title{
Leadership discourse stereotypes - Ericsson CEO's letter to employees
}

Hans Vestberg served as the latest CEO of Ericsson between 2010 and 25 July 2016. During his first years as CEO, the company solidified its strong position and reputation in the international market. Recently, after months of criticism, with Swedish media questioning his pay and many external leadership 


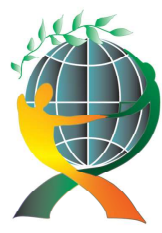

\author{
(online) $=$ ISSN $2285-3642$ \\ ISSN-L = 2285 - 3642 \\ Journal of Economic Development, Environment and People \\ Volume 6, Issue 4, 2017 \\ URL: http://jedep.spiruharet.ro \\ e-mail: office jedep@spiruharet.ro
}

assignments, and following increasing discontent among stockholders due to fall in net sales and a 26 per cent plunge in net income, Vestberg was forced to step down on 25 July 2016.

Hans Vestberg's first letter as CEO to Ericsson's employees (2010) is rather atypical in that it does not follow the normally used pattern of starting with a self-presentation and continuing with vision presentation and relationship building, by connecting informational and motivational goals. Unlike Nokia's CEO Suri, who started and ended his letter with personal and emotional self-disclosure, Vestberg, in spite of his international experience, can be seen to comply with a traditional Swedish stereotype of nonassertiveness: "Strong emotions are rarely expressed openly in Sweden, so indirect forms are used instead as compensation." (Holmberg \&Åkerblom2007: 11).

Nevertheless, even by Swedish standards, the way in which Vestberg starts his letter is unexpectedly un-rhetorical: the first statements provide, on a neutral and impersonal note, a matter-of-fact evaluation of the previous year's investment and financial performance: "2009 was a year of mixed trends and with varied operator investment behaviour. Some markets were impacted by the financial climate while others continued to show growth." These are statements that could very well have been made by a neutral external observer, but not by the CEP of Ericsson.

Vestberg gives a brief summary of Ericsson's unsatisfactory market results, which he accounts for in terms of the "challenging economic environment" during the previous year. Worth noting is the absence of human agents, with the exception of two instances: "we [1] maintained market shares" and "we [2] undertook significant cost reduction activities". The first person pronominal agents fulfil two different indexical functions: we [1] is referring to the company as a whole, whereas we [2] refers solely to the company's leadership team. It is symptomatic that no human agents are held accountable for the negative results: "During the year we undertook significant cost reduction activities. These, in combination with large losses in our joint ventures, affected our earnings negatively."Such a strategy is somehow predictable in manipulative leadership discourse, since in times of low performance levels or severe losses, leadership representatives tend to deliver the bad news strategically by pointing to external circumstances and events, so as to avoid taking responsibility (Thomas, 1997).

His ideas about the future are expressed by means of successive commissive speech acts performed in the first person plural "we": "We will connect people"; "we will connect our cars and trucks to smart road systems". However, these statements can hardly make an impact on the audience, since they fail to outline a clear focus and a shared commitment to core values and goals for the joint work that lies ahead. As has been pointed out in previous research (e.g. Edström and Jönsson (1998), Swedish leadership is vague and imprecise: "the typical Swedish order is 'See what you can do about it!' What does it mean? It obviously has to do with a far-reaching delegation of authority. Managers who say 'See what you can do about it!' demonstrate trust for their co-workers." (Edström \& Jönsson, 1998: 167). However, in an increasingly global world with very high levels of dynamics, complexity and competitiveness, this stereotypical Swedish leadership pattern has been undergoing considerable changes lately. Swedish leaders may still prefer to practice a leadership based on an informal and coaching role that leaves space for own initiatives, but they have also started to adjust their leadership styles by providing straightforward guidelines, establishing clear targets, and, above all, engaging and inspiring their co-workers to do their best (Holmberg \& Åkerblom, 2006). As a result, recent studies on Swedish leadership have pointed out a rather paradoxical situation 


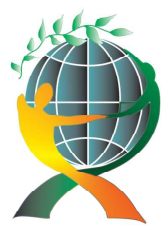

\author{
(online) $=$ ISSN $2285-3642$ \\ ISSN-L = 2285 - 3642 \\ Journal of Economic Development, Environment and People \\ Volume 6, Issue 4, 2017 \\ URL: http://jedep.spiruharet.ro \\ e-mail: office jedep@spiruharet.ro
}

with a combination of autonomy and team integration, which can be understood as a mirror of the peculiar Swedish combination of individualism and independence on the one hand, and collectivism and cooperation on the other (Holmberg \& Åkerblom, 2007).

Vestberg, known for his long-term policy orientation, is simply ventriloquizing the agenda-setting for the "new decade" in terms of organizational mission and goals. But in the process he loses sight of the short-term objectives and the need to motivate the employees to embrace the change by appealing to shared core values and a sense of belonging to Ericsson. The measures of success indicated by him in the last statement above are exclusively performance-oriented with no inspirational appeal to collective commitment, organizational belonging, and interpersonal bonding. The very last paragraph contains the only sentence in the whole letter which is delivered in the first person singular pronoun "I": "I am proud and honoured to lead Ericsson into a new decade where we will undoubtedly break new ground." Vestberg's approach to self-presentation is totally different from Suri's approach. While generally following a Swedish leadership model that is consensus-based, he also enacts the features of a laissez-faire leadership discourse whereby he assigns considerable responsibility with subordinates, but without setting clear guidelines or trying to reach a collective commitment.

\title{
Conclusion
}

Organisational culture contexts and social practices generate implicit models of leadership that are enacted based on institutionally and culturally grounded values. The focus of the present investigation was on the discursively articulated performance of leadership in the context of competition-driven organizational change. It explored stereotypes and counter-stereotypes in discourses of leadership in a comparative perspective, scrutinising the ways in which they contribute to constructing and re-constructing corporate and culture-related identities, as well as being impacted by them. Drawing on presentations in letters to employees by the CEOs of two multinational companies, Nokia (Finland) and Ericsson (Sweden), a comparative analysis of the challenges of leadership discourse practices was carried out in a discourseanalytical and pragma-rhetorical perspective. Doing leadership, always a cornerstone in discursively and interactively articulating the re-contextualisation and re-invention of these two companies, has often worked differently in the two cases, in terms of innovative change and competitive advantage. This comparison provides evidence for the varying internal and external challenges underlying leadership discursive construction and re-construction aimed at ensuring shared commitment and interconnectedness between a company's values and its competitive performance qualities.

Starting with commonalities, the analysis has revealed a number of significant differences between the leadership discourse styles displayed by two CEOs, Nokia's CEO Rajeev Suri and Ericsson's CEO Hans Vestberg. Two main categories of stereotypes have been revealed: on the one hand, the stereotypical representation of Finnish and Swedish leadership practices as undifferentiated 'Scandinavian'; on the other hand, the stereotypical representation of each of the two leadership practices as 'homogeneous' and enacting national identity features.

The examination of Rajeev Suri's first letter as CEO of Nokia reveals a multi-dimensional leadership style in terms of strength of purpose, topical focus, level of commitment, discursive strategies, audience involvement and relationship-building. His style exhibits both stereotypical and counter-stereotypical patterns of CEO leadership discourse. While generally following a Finnish leadership model that is 


\author{
(online) $=$ ISSN $2285-3642$ \\ ISSN-L = $2285-3642$ \\ Journal of Economic Development, Environment and People \\ Volume 6, Issue 4, 2017 \\ URL: http://jedep.spiruharet.ro \\ e-mail: office jedep@spiruharet.ro
}

consensus-based, but also partly authoritative, he also displays the features of a participative leadership discourse whose aim is to motivate and empower the workforce to actively and jointly participate in vision creation, goal setting and problem solving.

Vestberg's style exhibits both stereotypical and counter-stereotypical patterns of CEO leadership discourse. While generally following a Swedish leadership model that is consensus-based, he also enacts the features of a laissez-faire leadership discourse whereby he assigns considerable responsibility with subordinates, but without setting clear guidelines or trying to reach a collective commitment.

\title{
7. References
}

[1] Argenti, P. A.; Forman, J. (2004).The Power of Corporate Communication: Crafting the Voice and Image of Your Business. New York: McGraw Hill.

[2] Austin, J. L. (1962). How to Do Things with Words. Cambridge, MA: Harvard University Press.

[3] Beerel, A. (2009). Leadership \& Change Management. London: Sage.

[4] Berger, P. L. and Luckmann, T. (1966).The Social Construction of Reality. Garden City, NY: Anchor Books.

[5] Carroll, B.; Levy, L.; Richmond, D. (2008). Leadership as Practice: Challenging the Competency Paradigm. Leadership 4(4): 363-379.

[6] Clifton, J. (2012). A Discursive Approach to Leadership Doing Assessments and Managing Organizational Meanings. Journal of Business Communication 49(2), 148-168.

[7] Czarniawska-Joerges, B. (1993). Sweden: A Modern Project, a Postmodern Implementation. In: David J. Hickson (ed.), Management in Western Europe: Society, Culture and Organization in Twelve Nations, 229-247. Walter de Gruyter.

[8] Edström, A.; Jönsson, S. (1998). Svenskt Ledarskap. In Czarniawska, B. (ed.) Organisationsteori på Svenska. Malmö: Liber.

[9] Emirbayer, M.;Mische, A. (1998). What is Agency? The American Journal of Sociology, 103(4): 962-1023.

[10] Fairhurst, G. T.; Connaughton, S. L. (2014). Leadership: A Communicative Perspective. Leadership, 10(1): 7-35.

[11] Fairhurst, G. T.; Putnam, L. (2004).Organizations as Discursive Constructions.Communication Theory 14(1): 5-26.

[12] Hayward, J. E.S. (ed). (1995). Industrial Enterprise and European Integration: From National to International Champions in Western Europe. Oxford University Press, New York.

[13] Heracleous, L.; Marshak, R. J. (2004).Conceptualizing Organizational Discourse as Situated Symbolic Action.Human Relations 57: 1285-1312.

[14] Hill, C. W. L.; Jones, T. M. (1992).Stakeholder-Agency Theory.Journal of Management Studies 29(2): $131-154$. 


\author{
(online) $=$ ISSN $2285-3642$ \\ ISSN-L = $2285-3642$ \\ Journal of Economic Development, Environment and People \\ Volume 6, Issue 4, 2017 \\ URL: http://jedep.spiruharet.ro \\ e-mail: office jedep@spiruharet.ro
}

[15] Holmberg, I.; Åkerblom, S. (2007). Primus Inter Pares: Leadership and Culture in Sweden. In Chokar, J. S.; Brodbeck, F. C.; House, R. J. (eds.) Culture and Leadership across the World: The GLOBE Book of In-Depth Studies of 25 Societies. Mahwah, New Jersey: Lawrence Erlbaum Associates Inc.

[16] Ilie, C. (2007). British 'Consensus' versus Swedish 'Samförstånd' in Parliamentary Debates. In G. Garzone and C. Ilie (eds.) The Use of English in Institutional and Business Settings: An Intercultural Perspective, 101-125. Bern: Peter Lang.

[17] Karlsson, S.; Lugn, A. (2009).Changing the World.The Story of Lars Magnus Ericsson and His Successors. Stockholm: Sellin\& Partner.

[18] Kotter, J. P. (1988). The Leadership Factor. New York: Free Press.

[19] Kotter, J. P. (1996). Leading Change. Boston: Harvard Business School Press.

[20] Lämsä, T. (2010).Leadership Styles and Decision-Making in Finnish and Swedish Organizations.Review of International Comparative Management 11(1): 139-149.

[21] Leech, G. (1983). Principles of Pragmatics. London: Longman.

[22] Lindén, C-G. (2012). National Champions in Combat: Nokia, Ericsson and the Sensemaking of Business News. PhD thesis, University of Helsinki.

[23] Luhtakallio, E. (2010). Local Politicizations: A Comparison of Finns and French Practicing Democracy. University of Helsinki, Helsinki.

[24] Phillips, N.; Hardy, C. (2002).Discourse Analysis: Investigating Processes of Social Construction. Thousand Oaks, California: Sage.

[25] Putnam, L. L.; Fairhurst, G. T. (2001). Discourse Analysis in Organizations: Issues and Concerns. In F. M. Jablin\& L. L. Putnam (eds.), The New Handbook of Organizational Communication: Advances in Theory, Research, and Methods: 78-136. London: Sage.

[26] Raelin, J. A. (ed.). (2016). Leadership-as-Practice: Theory and Application. New York and London: Routledge.

[27] Searle, J. R. (1969). Speech Acts: An Essay in the Philosophy of Language. Cambridge University Press, Cambridge.

[28] Searle, J. R. (1975). Indirect Speech Acts. In P. Cole \& J. L. Morgan (eds), Syntax and Semantics 3: Speech Acts, 5982. New York: Academic Press.

[29] Smith, P. B.; Andersen, J. A.; Ekelund, B.; Graversen, G. \&Ropo, A. (2003).In Search of Nordic Management Styles.Scandinavian Journal of Management 19: 491-507.

[30] Thomas, J. (1983). Cross-Cultural Pragmatic Failure.Applied Linguistics 4: 91-112. 


\author{
(online) $=$ ISSN $2285-3642$ \\ ISSN-L = 2285 - 3642 \\ Journal of Economic Development, Environment and People \\ Volume 6, Issue 4, 2017 \\ URL: http://jedep.spiruharet.ro \\ e-mail: office jedep@spiruharet.ro
}

[31] Thomas, J. (1997). Discourse in the Marketplace: The Making of Meaning in Annual Reports. International Journal of Business Communication 34(1): 47-66.

[32] Tyrstrup, M. (2005).Sovereigns of Time: A Scandinavian View of Executive Work, Time and Leadership. Lund: Studentlitteratur. 